\title{
THE CONTROL OF INTRANUCLEAR DISTRIBUTION OF CHIASMATA IN DELPHINIUM
}

\author{
H. K. JAIN and N. MAHERCHANDANI \\ Botany Division, Indian Agricultural Research Institute, New Delhi
}

\section{INTRODUCTION}

Received 18.iv.61

Although the inter-bivalent distribution of chiasmata has not been studied as extensively as the intra-bivalent, evidence has been available for a long time about its variable nature. Thus, Mather (1936) concluded, following chiasma frequency analysis in twenty seven different organisms, that negatively correlated chiasma frequencies occur in the two or more groups of chromosomes in the nuclei of a number of species but not of all. The non-universal character of this type of chiasmata distribution was also indicated by the observation that while some individuals of a species show negatively correlated chiasma frequencies, others may fail to do so and a further group shows them with respect to some bivalents only. The present analysis in Delphinium was undertaken after evidence had been obtained in the course of an earlier investigation on this plant, that experimentally induced changes in the number of chiasmata in two large bivalents, affect their frequency in the six small bivalents (Jain and Bose, 1960). This was observed in a number of plants analysed and it was felt that further studies on this material might prove to be of interest in relation to the above problem.

\section{MATERIAL}

Plants of Delphinium ajacis var. "Comet", a winter annual with a diploid chromosome number of $\mathrm{i} 6$ were grown as controls to colchicine induced tetraploids. Flower buds from five of these diploid plants were fixed in Carnoy to which a few drops of aqueous ferric chloride solution ( 1 per cent.) had been added for mordanting. The chiasma frequency scoring for detailed analysis was done at metaphase in temporary acetocarmine preparations. Pollen mother cells at early diakinesis when the chiasmata were not liable to any confusion, were also scored to find whether or not the two sets of observations show the same trend. Of the eight chromosome pairs in Delphinium, all of which are of fairly large size, two are considerably larger than the other six (figs. I, 2) and this easy separation of the bivalents into two groups as well as the fact that a large number of cells can be easily analysed, makes the plant of considerable value for studies on inter-chromosome distribution of chiasmata. On the other hand, unlike organisms, such as Vicia, there is terminalisation of chiasmata in Delphinium as prophase advances and it has been supposed on the basis of considerations pointed out in the following section, that metaphase scoring gives results comparable to those at diplotene.

\section{METHOD}

In order to find out whether the chiasma frequencies in the large and small groups of chromosomes show any correlation, the method described by Elliott (1958) has been followed. This method involves the determination of inter-nuclear 
variance which measures the variation in the total number of chiasmata among the pollen mother cells, and inherent variance which measures the variation in the distribution of chiasmata between the bivalents of the individual cells. If the internuclear variance exceeds the inherent variance, a positive correlation is suggested. A negative correlation is indicated, on the other hand, if the inherent variance is greater than the inter-nuclear variance. As all the eight bivalents in Delphinium cannot be distinguished from one another-they can be separated into only two distinct groups-the inherent variance has been calculated to measure the variation in the distribution of chiasmata within the large and the small chromosome groups. The components of variation for $n$ nuclei in Delphinium, then, are as follows :

\begin{tabular}{|c|c|c|}
\hline Source of variation & & Degrees of freedom \\
\hline Tot & . & $2 n-1$ \\
\hline Between nuclei (inter-nuclear) & . & $n-\mathbf{I}$ \\
\hline en groups of bivalents & (i) & $\stackrel{\mathrm{I}}{\mathrm{I}(n-\mathrm{I})}$ \\
\hline
\end{tabular}

The last-named component has been designated as the inherent variance for the purpose of the present analysis. Correlation coefficients for the two groups of chromosomes were calculated employing the standard formula :

$$
r=\frac{\operatorname{Cov}_{x y}}{\sqrt{\left(\text { Variance }_{x}\right)\left(\text { Variance }_{y}\right)}}
$$

where $x$ and $y$ refer to chiasma frequencies in two groups.

\section{RESULTS}

(i) Chiasma frequencies, inter-nuclear and inherent variances

The observations on mean chiasma frequencies of each of the five plants are summarised in table I. Also given in this table are the corresponding inter-nuclear and inherent variances.

The observations in table I show that at both metaphase and early diakinesis, inherent variance exceeds inter-nuclear variance. This is true for all the five plants and the difference has been found to be statistically significant in the case of four of them, the first three plants showing this significant difference both at metaphase and diakinesis. The analysis at the two stages thus provides evidence for a negative correlation between the chiasmata in the large and the small groups of bivalents. The fact that early diakinesis and metaphase observations show the same trend makes it possible to suppose that terminalisation does not significantly change the earlier condition with regard to the intra-nuclear distribution of chiasmata. Such an alteration would occur if the process of terminalisation in different bivalents is negatively correlated. As pointed out by Mather (loc. cit.), it is difficult to imagine such a correlation, particularly when terminalisation is complete. Hardly any interstitial chiasmata were found in the metaphase bivalents in the present material.

An examination of the observations in table I also shows that the negative correlation occurs in the case of plants showing relatively high mean chiasma frequency as well as others showing lower mean values and thus appears to be independent of such values. A $t$ test, performed for their metaphase mean values showed that plants I 
and 2 and 2 and 3 have significantly different frequencies. Also, a test of heterogeneity of variances (table IA) shows that the five plants differ in their inter-nuclear variance but not in inherent variance. In spite of differences in their inter-nuclear variance, however, all the five plants give indication of a negative inter-group correlation.

TABLE I

Analysis of variance of chiasma frequency

\begin{tabular}{|c|c|c|c|c|c|}
\hline \multirow{2}{*}{ Plant no. } & $\begin{array}{c}\text { No. of } \\
\text { cells }\end{array}$ & $\begin{array}{c}\text { Mean Xta } \\
\text { per cell }\end{array}$ & $\begin{array}{c}\text { Inter-nuclear } \\
\text { variance }\end{array}$ & $\begin{array}{c}\text { Inherent } \\
\text { variance }\end{array}$ & Correlation \\
\hline \multicolumn{1}{|c|}{ (Metaphase) } \\
\hline \\
\hline
\end{tabular}

* Correlation negative, significant at 5 per cent. level.

$\uparrow$ Correlation, not significant.

TABLE IA

Test of heterogeneity of variances in table I

\begin{tabular}{|c|c|c|c|c|c|c|}
\hline & \multicolumn{3}{|c|}{ Inter-nuclear variance } & \multicolumn{3}{|c|}{ Inherent variance } \\
\hline & $x^{2}$ & D.f. & $P$ & $\chi^{2}$ & D.f. & $\mathrm{P}$ \\
\hline Metaphase & $16 \cdot 9^{88}$ & 4 & $0.01-0.001$ & $2 \cdot 2934$ & 4 & $0.7-0.5$ \\
\hline Diakinesis . & $7 \cdot 9305$ & 4 & $0.1-0.05$ & 3.9278 & 4 & $0 \cdot 5-0 \cdot 3$ \\
\hline
\end{tabular}

This shows that significant heterogeneity among inter-nuclear variances does not necessarily determine the direction of correlations as was suggested by the observations of Elliott (1958) on Endymion. The existence of large inter-nuclear variances in several of the plants, on the other hand, suggests the need for extending the analysis to the level of individual cells within a plant. 


\section{(ii) Intra-plant, inter-cell variation in chiasma frequency and inherent variance}

The observations on the chiasma frequency described above are presented in a different manner to show the intra-plant, inter-cell distributions.

These distributions make it clear that the different pollen mother

TABLE 2

Intra-plant inter-cell variation in the distribution of chiasmata in large and small group bivalents at metaphase

\begin{tabular}{|c|c|c|c|c|c|c|}
\hline \multirow{3}{*}{$\begin{array}{l}\text { Plant } \\
\text { no. }\end{array}$} & \multirow{3}{*}{$\begin{array}{l}\text { No. of chiasmata } \\
\text { in large bivalents }\end{array}$} & \multicolumn{5}{|c|}{ No. of chiasmata in small bivalents } \\
\hline & & 5 & 6 & 7 & 8 & 9 \\
\hline & & \multicolumn{5}{|c|}{$\begin{array}{l}\text { No. of cells showing stated chiasma frequency } \\
\text { in the two groups of bivalents }\end{array}$} \\
\hline I & $\begin{array}{l}6 \\
5 \\
4 \\
3 \\
2\end{array}$ & $\begin{array}{c}\ldots \\
\ldots \\
2 \\
\cdots \\
\cdots\end{array}$ & $\begin{array}{r}\mathrm{I} \\
8 \\
4 \mathrm{I} \\
\mathrm{IO} \\
4\end{array}$ & $\begin{array}{r}\ldots \\
3 \\
14 \\
10 \\
1\end{array}$ & $\begin{array}{c}\ldots \\
\ldots \\
2 \\
3 \\
1\end{array}$ & $\begin{array}{l}\ldots \\
\ldots \\
\ldots \\
\cdots \\
\cdots\end{array}$ \\
\hline 2 & $\begin{array}{l}4 \\
3 \\
2\end{array}$ & $\begin{array}{l}\cdots \\
\cdots \\
\cdots\end{array}$ & $\begin{array}{r}32 \\
34 \\
\mathrm{I}\end{array}$ & $\begin{array}{r}7 \\
20 \\
4\end{array}$ & $\begin{array}{c}\ldots \\
2 \\
\cdots\end{array}$ & $\begin{array}{l}\cdots \\
\cdots \\
\cdots\end{array}$ \\
\hline 3 & $\begin{array}{l}5 \\
4 \\
3 \\
2\end{array}$ & $\begin{array}{l}\ldots \\
\ldots \\
\cdots \\
\cdots\end{array}$ & $\begin{array}{r}4 \\
33 \\
13 \\
1\end{array}$ & $\begin{array}{r}1 \\
24 \\
16 \\
\cdots\end{array}$ & $\begin{array}{r}\ldots \\
3 \\
4 \\
\ldots\end{array}$ & $\begin{array}{c}\ldots \\
\ldots \\
\text { I } \\
\ldots\end{array}$ \\
\hline 4 & $\begin{array}{l}6 \\
5 \\
4 \\
3\end{array}$ & $\begin{array}{l}\ldots \\
\ldots \\
\cdots \\
\cdots\end{array}$ & $\begin{array}{r}1 \\
7 \\
30 \\
6\end{array}$ & $\begin{array}{r}\cdots \\
69 \\
3\end{array}$ & $\begin{array}{c}\cdots \\
1 \\
12 \\
2\end{array}$ & $\begin{array}{c}\ldots \\
\text { I } \\
2 \\
\ldots\end{array}$ \\
\hline 5 & $\begin{array}{l}6 \\
5 \\
4 \\
3 \\
2\end{array}$ & $\begin{array}{l}\ldots \\
\cdots \\
\cdots \\
\cdots \\
\cdots\end{array}$ & $\begin{array}{r}\mathrm{I} \\
3 \\
38 \\
34 \\
\ldots\end{array}$ & $\begin{array}{r}1 \\
2 \\
11 \\
6 \\
1\end{array}$ & $\begin{array}{r}\ldots \\
\ldots \\
\mathrm{I} \\
2 \\
\cdots\end{array}$ & $\begin{array}{l}\ldots \\
\ldots \\
\ldots \\
\ldots \\
\ldots\end{array}$ \\
\hline
\end{tabular}

cells of a plant can be divided into several groups. This has been done by placing the cells showing the same number of chiasmata at metaphase in one separate group. Four such groups having cells with 9, Io, I I and 12 chiasmata respectively have been thus obtained. Cells showing chiasma frequency beyond the range of 9-12 are very few in number (less than five) and have not been considered here. Fewer than five cells in any of the above four groups have also been discarded for the purpose of intra-plant analysis. The cells within each of the 
four groups have been shown to exhibit no inter-nuclear variance and it has been of interest to see how the inherent variance varies in them. This inter-cell group variation in respect of inherent variance for the five plants taken both separately and collectively, is shown in table 3 .

The results presented in table 3 show that with increase in the

TABLE 3

Intra-plant, inter-cell group variation in inherent variance

\begin{tabular}{|c|c|c|c|c|c|c|c|c|}
\hline \multicolumn{9}{|c|}{ Inherent variance for different cell groups } \\
\hline \multirow{2}{*}{$\begin{array}{l}\text { Plant } \\
\text { no. }\end{array}$} & \multicolumn{2}{|c|}{ Group I (9 Xta) } & \multicolumn{2}{|c|}{ Group 2 ( $10 \mathrm{Xta}$ ) } & \multicolumn{2}{|c|}{ Group 3 (I I Xta) } & \multicolumn{2}{|c|}{ Group 4 ( 12 Xta) } \\
\hline & $\begin{array}{l}\text { No. of } \\
\text { cells }\end{array}$ & $\begin{array}{l}\text { Inherent } \\
\text { variance }\end{array}$ & $\begin{array}{l}\text { No. of } \\
\text { cells }\end{array}$ & $\begin{array}{l}\text { Inherent } \\
\text { variance }\end{array}$ & $\begin{array}{l}\text { No. of } \\
\text { cells }\end{array}$ & $\begin{array}{l}\text { Inherent } \\
\text { variance }\end{array}$ & $\begin{array}{l}\text { No. of } \\
\text { cells }\end{array}$ & $\begin{array}{l}\text { Inherent } \\
\text { variance }\end{array}$ \\
\hline I & I3 & 0.1625 & $5^{2}$ & 0.1468 & 25 & 0.2152 & 6 & 0.3148 \\
\hline 2 & $3^{8}$ & 0.0644 & $5^{2}$ & $0 \cdot 1608$ & 9 & 0.1297 & $\ldots$ & \\
\hline 3 & 13 & $0 \cdot 0000$ & 49 & o. I 496 & 32 & 0.1804 & 5 & 0.3332 \\
\hline 4 & 6 & 0.0000 & 33 & 0.0568 & 38 & 0.1368 & 19 & 0.2456 \\
\hline 5 & 35 & o.or 90 & 44 & 0.0803 & I 6 & 0.2194 & $\ldots$ & $\ldots$ \\
\hline $\begin{array}{c}\mathrm{I}-5 \\
\text { Popled }\end{array}$ & 105 & 0.0503 & 230 & 0.1306 & I 20 & 0.1923 & 30 & 0.3073 \\
\hline & & & & & & & & \\
\hline
\end{tabular}

TABLE 3 A

Test of heterogeneity of inherent variances in table 3

\begin{tabular}{|c|c|c|c|}
\hline Plant no. & $\chi^{2}$ & D.f. & $\mathrm{P}$ \\
\hline $\begin{array}{l}\text { I } \\
2 \\
3 * \\
4^{*} \\
5 \\
\text { I-5 Pooled }\end{array}$ & $\begin{array}{r}3 \cdot 9899 \\
8 \cdot 1408 \\
\mathrm{I} \cdot 5277 \\
\mathrm{I} 2 \cdot 8834 \\
\mathrm{I} 4 \cdot 4739 \\
58 \cdot 3599\end{array}$ & $\begin{array}{l}3 \\
2 \\
2 \\
2 \\
2 \\
3\end{array}$ & $\begin{array}{l}0.3-0.2 \\
0 \cdot 02-0 \cdot 01 \\
0 \cdot 5-0.3 \\
0 \cdot 01-0.001 \\
0 \cdot 01-<0.001 \\
0.01-<0.001\end{array}$ \\
\hline
\end{tabular}

* The cell groups with o inherent variance have been left out from the test of heterogeneity.

number of chiasmata in the cells, the inherent variance in most cases also increases. To see whether this apparent increase is statistically significant, Bartlett's test for heterogeneity of variances was performed for individual plants as well as the pooled data (table $3 \mathrm{~A}$ ). Inherent variances for different cell groups in plants 2,4 and 5 are found to be heterogeneous, and so also the inherent variances in the case of pooled data which obviously has greater reliability as the variances were based on larger number of degrees of freedom. The general trend of observations on all the plants as well as the analysis of pooled data, leads to the conclusion, that the inherent variances in different cell 
groups are positively correlated with their chiasma frequencies. The increase in the number of chiasmata is not expected, as such, to lead to as large variances as observed. The expected rate of increase in variance on a purely numerical basis, is the squared rate of increase in mean. Considering the two extreme cell groups I and 4 , the expected increased variance of group 4 would be $12^{2} / 9^{2}$ times variance of group I, whereas in the case of pooled data, this increase is nearly six times. A considerable part of the observed increase must therefore be attributed to other factors. If it is assumed that competition leads to greater variance, the above results would show that the interbivalent competition for chiasmata for which evidence has already been presented, increases with increase in the number of chiasmata in a cell. The assumption is not without evidence, although it is derived from observations of a very different kind. Experimental findings of Sakai (1955) and Griffing (1953) on variances for quantitative characters in plants are compatible with this assumption.

(iii) Intra-plant variation in correlation coefficients

The effect of increase in chiasma frequency on intra-nuclear distribution of chiasmata can also be shown by calculating correlation coefficients of chiasmata in the two groups of bivalents. For this purpose, the pollen mother cells of each plant have been divided into two groups; cells with a chiasma frequency of more than io constituting the A group, those having io or fewer chiasmata the B group. The correlation coefficients for these two groups of cells in each of the five plants are given in table 4 .

It is found that the negative correlation coefficient is stronger in the group A pollen mother cells in all the five plants, significantly so in three of them. If the inherent and inter-nuclear variances are determined for these two groups of cells, as has been done in table 5, it is observed that the inherent variance is greater in the A group cells than in the B group in four of the plants; in two of them, this is associated with an inter-nuclear variance which is smaller than the corresponding variance in the B group. The above results are thus in agreement with those presented earlier in showing greater variation in the distribution of chiasmata and greater inter-bivalent competition in cells with relatively higher number of chiasmata.

\section{DISCUSSION}

The genotypic control of chiasma frequency was demonstrated convincingly by Rees (I 955) following his observations on crosses between inbred strains of rye. It has also been known, as pointed out earlier, that distribution of chiasmata in a plant may not be independently determined. More recently Rowlands (1958) has shown that in different plants of Vicia faba, there is a wide range of correlation coefficients, from negative correlations that are highly significant to positive which approach the level of significance. Variable 
behaviour of this type has also been demonstrated by Elliott (r958) in Endymion and hyacinths. Both Rowlands and Elliott further found that the correlation coefficients are not related to mean chiasma frequencies in the plants. The present observations on Delphinium indicate that it is not possible to relate the inter-bivalent correlations with mean chiasma frequencies in the plants. The Delphinium results, however, are of further interest for two reasons. The fact that all the five plants show or tend to show correlation of the negative type

TABLE 4

Coefficients of correlation

\begin{tabular}{|c|c|c|c|c|c|c|c|c|c|}
\hline \multirow{2}{*}{$\begin{array}{c}\text { Plant } \\
\text { no. }\end{array}$} & \multicolumn{4}{|c|}{ Group A cells } & \multicolumn{4}{|c|}{ Group B cells } & \multirow{2}{*}{$\begin{array}{c}t\left(\mathrm{I} \cdot 3^{6} \text { at }\right. \\
5 \text { per cent } \\
\text { level) }\end{array}$} \\
\hline & $\begin{array}{l}\text { No. of } \\
\text { ceills }\end{array}$ & $\begin{array}{c}\text { Mean } \\
\text { Xta }\end{array}$ & $r$ & $z$ & $\begin{array}{l}\text { No. of } \\
\text { cells }\end{array}$ & $\begin{array}{c}\text { Mean } \\
\text { Xta }\end{array}$ & $r$ & $z$ & \\
\hline I & 31 & II 19 & $-0.803 \mathrm{I}$ & I. I 066 & 69 & $9 \cdot 69$ & -0.5172 & & $2 \cdot 379$ \\
\hline 2 & 9 & II 00 & -0.9982 & 3.0000 & 91 & $9 \cdot 5^{6}$ & -0.4913 & 0.5377 & 5.763 \\
\hline 3 & 37 & II 13 & -0.8354 & I. 2056 & $\mathrm{\sigma}_{3}$ & $9 \cdot 76$ & -0.5618 & 0.6355 & $2 \cdot 615$ \\
\hline 4 & 61 & II 45 & $-0.593^{2}$ & 0.6826 & 39 & $9 \cdot 3^{8}$ & $-0.5^{26} 63$ & $0.5^{8} 50$ & $0 \cdot 788$ \\
\hline 5 & $2 \mathrm{I}$ & I I $\cdot 28$ & -0.7107 & 0.8886 & 79 & 9.55 & $-0.3^{6} 33$ & $0 \cdot 3^{868}$ & I.90o \\
\hline
\end{tabular}

TABLE 5

Analysis of variance of chiasma frequency in the $A$ and $B$ groups of cells

\begin{tabular}{|c|c|c|c|c|c|c|c|c|}
\hline \multirow{2}{*}{$\begin{array}{c}\text { Plant } \\
\text { no. }\end{array}$} & \multicolumn{4}{|c|}{ Group A cells } & \multicolumn{4}{|c|}{ Group B cells } \\
\hline & $\begin{array}{l}\text { No. of } \\
\text { cells }\end{array}$ & $\begin{array}{c}\text { Mean } \\
\text { Xta }\end{array}$ & $\begin{array}{c}\text { Inter- } \\
\text { nuclear } \\
\text { variance }\end{array}$ & $\begin{array}{l}\text { Inherent } \\
\text { variance }\end{array}$ & $\begin{array}{l}\text { No. of } \\
\text { celis }\end{array}$ & $\underset{\text { Xta }}{\text { Mean }}$ & $\begin{array}{c}\text { Inter- } \\
\text { nuclear } \\
\text { variance }\end{array}$ & $\begin{array}{l}\text { Inherent } \\
\text { variance }\end{array}$ \\
\hline I & $3 I$ & I I I I & 0.0201 & 0.3009 & $6 g$ & $9 \cdot 69$ & 0.0415 & 0.2072 \\
\hline 2 & 9 & I I $\cdot 00$ & 0.0017 & O.I5II & $9 I$ & $9 \cdot 56$ & 0.0328 & 0.2699 \\
\hline 3 & 37 & I I I I 3 & o.0oI 5 & 0.1787 & 63 & $9 \cdot 76$ & $0.027 \mathrm{I}$ & 0.1480 \\
\hline 4 & $6 i$ & I I 45 & $0.055^{8}$ & 0.2069 & 39 & $9 \cdot 3^{8}$ & 0.0167 & 0.0760 \\
\hline 5 & $2 \mathrm{I}$ & I I 28 & $0.039^{8}$ & 0.2946 & 79 & $9 \cdot 55$ & 0.0310 & 0.2012 \\
\hline
\end{tabular}

contradicts the conclusion reached by Rowlands that such correlations are of little significance, being the occasional outcome of the mechanism controlling chiasma frequency. Secondly, the observations recorded on a large number of pollen mother cells in each of the five plants, make it possible to extend the analysis to intra-plant level and find out whether the negative correlation in individual cells is a function of the total number of chiasmata formed in them. The significantly greater inherent variances in most cell groups showing higher number of chiasmata clearly shows that the inter-bivalent distribution of chiasmata is affected by their number in a cell. A 
similar conclusion has been described by Rees and Thompson (I956) on the basis of their detailed analysis of chiasma frequency variation in inbred and $F_{1}$ plants of rye. These authors found that bivalent variances and chiasma frequencies are negatively correlated between plants within inbred lines, but positively correlated within anthers of $\mathrm{F}_{1}$ plants. The heterozygous Delphinium plants correspond more to the hybrids. Assuming that greater variance in Delphinium results from greater competition, the almost linear increase in inherent

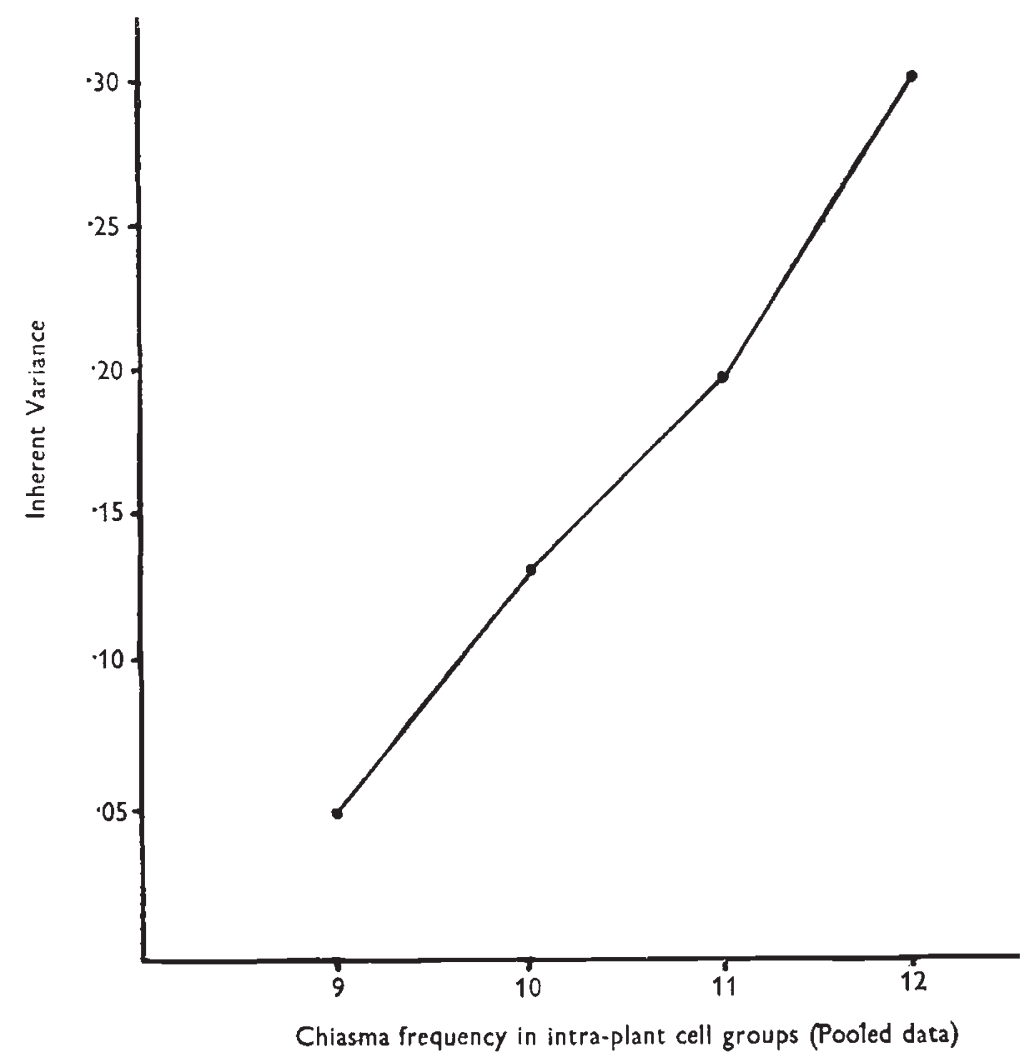

TEXT-FIG. 3.-Variation in the inherent variance with chiasma frequency changes in the cells.

variance with increasing number of chiasmata (text-fig. 3) indicates that at lower levels of chiasma frequency, the inter-bivalent distribution of chiasmata is to a large extent independently determined. In other words, each of the bivalents is adapted to form a minimum number of chiasmata, beyond which competition sets in for the extra number of chiasmata, formed in the nucleus. Even if the above assumption is not made, the significantly greater correlation coefficient in the A group cells with their higher number of chiasmata would point to the same conclusion. A similar conclusion was reached earlier by Mather (loc. cit.) on the basis of observations of a different type made 
by Lamm (I936) on rye plants. Lamm found that inbred rye with a low chiasma frequency fails to show inter-chromosome competition whereas ordinary rye with a higher chiasma frequency shows it often. Also, the recent finding of Wilson (I959) that experimentally induced changes in chiasma frequency in Endymion, affect the long chromosomes more than the short ones, is understandable on the basis of the above conclusion. It may be supposed that the induced changes affect that fraction of the chiasma frequency for which there is competition and the larger bivalents are better adapted to have it.

Mather has explained how, with bivalents in the same nucleus showing very different frequencies of chiasmata, there may exist differences in the competing ability of the different bivalents, which would explain the variable behaviour with regard to the intra-nuclear distribution of chiasmata in different organisms. It is also possible to offer an explanation for the failure, reported by Rowlands, to find any consistent relationship when the mean chiasma frequencies of a number of individuals belonging to the same species and their respective inherent variances or correlation coefficients are considered. The number of chiasmata beyond which competition occurs between the bivalents, may vary in individuals showing genotypically determined differences in their chiasma frequencies. Such a threshold variation would mean that a plant with relatively high mean chiasma frequency would not necessarily show a larger correlation coefficient.

The above interpretation of intra-nuclear distribution of chiasmata is obviously of interest in relation to the mechanism of chiasma formation. The fact that intra-nuclear chiasma distribution beyond a certain level tends to be determined by competition points to a regulating control which naturally discounts the suggestion that chiasma formation may have a purely mechanical basis. Such a distribution, suggesting as it does a limit to chiasma formation in the bivalents, has interesting genetical implications. It appears to be a manifestation of the control determining the amount of genetic recombination. The control of this recombination is of obvious importance in relation to stability on the one hand and continued adaptability on the other. The competition for chiasmata beyond a certain frequency would also possibly result in greater variation among the recombinants. It is not, however, possible to suggest that inter-bivalent competition for chiasmata has been selected to secure this purpose.

The earlier observations on this plant showing that experimentally induced reduction in chiasma frequency in one group of chromosomes leads to an increase in the number of chiasmata in the other group is also of interest, in relation to this point. It corresponds to the finding of Morgan et al. (1933) that prevention of crossing over on two of the long chromosomes of Drosophila melanogaster was accompanied by increased crossing over in the third chromosome, and emphasises the control of the amount of genetic recombination. 


\section{SUMMARY}

I. Observations on the two groups of bivalents (large and small) in the pollen mother cells of five plants of Delphinium have indicated that their chiasma frequencies are negatively correlated.

2. It has been found that the inter-group correlation is stronger in cells with relatively higher number of chiasmata. The intra-plant analysis has also shown that when the different cell classes showing no inter-nuclear variance are considered, those with higher number of chiasmata show greater variation in the distribution of chiasmata among the two groups of bivalents.

3. The observations have been interpreted to indicate that at lower levels of chiasma frequency the intra-nuclear distribution of chiasmata among different bivalents is independently determined, but as the chiasma frequency rises, the bivalents show increasing competition.

4. The implication of these observations for the mechanism controlling chiasma formation has been briefly discussed. It has also been concluded that the inter-bivalent competition for chiasmata is a manifestation of the mechanism controlling amount of genetic recombination.

Acknowledgments.-We are grateful to Dr B. P. Pal for constant interest and encouragement. Our thanks are also due to Drs A. B. Joshi and S. K. Jain for a useful discussion of the results with us and to Mr Daljit Singh for advice with regard to statistical analysis.

\section{REFERENCES}

ELLIOTT, G. G. 1958. Environmental effects on the distribution of chiasmata among nuclei and bivalents and correlation between bivalents. Heredity, 12, 429-439.

GRIFFING, B. 1953. An analysis of tomato yield components in terms of genotypic and environmental effects. Iowa Agr. Exp. Sta. Research Bull., 397, 324-38o.

JAIN, H. K., AND BOSE, A. K. 1960. Experimentally induced inter-bivalent redistribution of chiasmata in Delphinium. Nature, I86, 260-26r.

LAMм, R. 1936. Cytological studies on inbred rye. Hereditas, 22, 21 7-240.

MATHER, K. I936. Competition between bivalents during chiasma formation. P.R.S., B, 120, 208-227.

MORGAN, T. H., BRIDGES, G. B., SCHULTZ, J. 1933. Constitution of the germinal material in relation to heredity. Carnegie Inst. rear book, 32, 298-302.

REES, H. 1955. Heterosis in chromosome behavior. P.R.S., B, I44, $150-159$.

REES, H., AND THOMPSON, J. в. 1956. Genotypic control of chromosome behavior in rye. III. Chiasma frequencies in homozygotes and heterozygotes. Heredity, 1o, 409-424.

Rowland, D. G. 1958. The control of chiasma frequency in Vicia faba L. Chromosoma, 9, , 76 -184.

SAKAI, K. 1955. Competition in plants and its relation to selection. Cold Spring Harbor Symp. Quant. Biol., 20, 137-157.

WILSON, J. Y. 1959. Changes in distribution of chiasmata in response to experimental factors in the blue bell, Endymion nonscriptus (L.) Gorke. Genetica, 3o, $4^{17-434}$. 